\title{
Impact and Modulations of Peripheral and Edaphic B Cell Subpopulations in Chronic Rhinosinusitis With Nasal Polyposis
}

\author{
Pascal Ickrath ${ }^{1} \cdot$ Norbert Kleinsasser $^{1} \cdot$ Xin Ding $^{2} \cdot$ Christian Ginzkey $^{3} \cdot$ Niklas Beyersdorf $^{2} \cdot$ Thomas Kerkau $^{2}$ \\ Rudolf Hagen ${ }^{1} \cdot$ Stephan Hackenberg ${ }^{1}$ \\ ${ }^{I}$ Department of Oto-Rhino-Laryngology, Plastic, Aesthetic and Reconstructive Head and Neck Surgery, University of Wuerzburg, Wuerzburg; \\ ${ }^{2}$ Institute for Virology and Immunobiology, University of Wuerzburg, Wuerzburg; \\ ${ }^{3}$ Department of Oto-Rhino-Laryngology, Head and Neck Surgery “Otto Körner”, University Medical Center Rostock, Rostock, Germany
}

Objectives. The pathophysiological mechanisms of chronic rhinosinusitis with nasal polyposis (CRSwNP) still are discussed controversially. Regulatory $\mathrm{B}$ cells $\left(\mathrm{B}_{\mathrm{reg}}\right)$ are responsible for the suppression of $\mathrm{T}$ cell activity: deficiencies for $\mathrm{B}_{\mathrm{reg}}$ have been demonstrated to contribute to autoimmune disorders, e.g., systemic lupus erythematosus. In order to evaluate the influence of B cell subpopulations, especially $\mathrm{B}_{\mathrm{reg}}$, on the etiology of this disease, the aim of this study was to characterize subpopulations of peripheral and edaphic B cells in CRSwNP.

Methods. Polypoid tissue and blood samples were collected from 10 patients undergoing paranasal sinus surgery and lymphocytes were analyzed by multicolor flow cytometry.

Results. There was a significantly lower frequency of B cells in nasal polyps compared to peripheral blood mononuclear cells (PBMC) in patients with CRSwNP. Mature resting B cells were the main population within B cells in PBMC, and memory B cells in nasal polyps. Remarkably, $\mathrm{B}_{\text {reg }}$ and mature B cells significantly decreased in nasal polyps compared to PBMC. Memory B cells significantly increased and represented the main subpopulation in nasal polyps in patients with CRSwNP.

Conclusion. In this study a detailed contemporary characterization of B cell subpopulations in patients with CRSwNP is presented. The influence of edaphic B cells could play a key role in the maintenance of this chronic infectious disease.

Keywords. Chronic Rhinosinusitis; Nasal Polyps; B Cells; Regulatory B Cells; Plasma Cells

\section{INTRODUCTION}

The development of nasal polyps subdivides the chronic rhinosinusitis (CRS) into two different phenotypes: CRS with nasal polyposis (CRSwNP) and CRS without nasal polyposis (CRSsNP). Up to date, the etiopathology of CRSwNP is still not fully

\footnotetext{
- Received October 15, 2017

Revised December 18, 2017

Accepted December 20, 2017

- Corresponding author: Pascal Ickrath

Department of Oto-Rhino-Laryngology, Plastic, Aesthetic and

Reconstructive Head and Neck Surgery, University of Wuerzburg,

Josef-Schneider-Str. 11, D-97080 Wuerzburg, Germany

Tel: +49-931-201-21288, Fax: +49-931-201-21321

E-mail: ickrath_p@ukw.de
}

understood: nasal polyps develop from nasal mucosal tissue of the medial nasal concha and the superior nasal passage $[1,2]$. Histopathologically, they are characterized by respiratory epithelium and edematous stroma, which is infiltrated by a multitude of inflammatory cells. With respect to European and U.S. patients, the main cell populations are eosinophilic and lymphatic cells with a predominant $\mathrm{T}_{\mathrm{H}} 2$ subtype, whereas neutrophil inflammatory cells and a Thelper $1\left(\mathrm{~T}_{\mathrm{H}} 1\right) / \mathrm{T}_{\mathrm{H}} 17$ subtype are predominant in Asian patients [3]. Newly, Bachert et al. [3] developed a classification of CRSwNP into different endotypes depending on the predominant inflammatory cells in a $\mathrm{T}_{\mathrm{H}} 2$-biased or a $T_{\mathrm{H}} 1 / \mathrm{T}_{\mathrm{H}} 17$-biased inflammation. This is of clinical interest due to the higher risk of disease recurrence and bronchial asthma comorbidity in the $\mathrm{T}_{\mathrm{H}} 2$ endotype together with high levels

Copyright (c) 2018 by Korean Society of Otorhinolaryngology-Head and Neck Surgery.

This is an open-access article distributed under the terms of the Creative Commons Attribution Non-Commercial License (http://creativecommons.org/licenses/by-nc/4.0)

which permits unrestricted non-commercial use, distribution, and reproduction in any medium, provided the original work is properly cited. 
of interleukin (IL)-5 and immunoglobulin E (IgE). According to Bachert et al. [3], a predominance of $\mathrm{CD} 8^{+} \mathrm{T}$ cells was shown in nasal polyps with a more effector memory phenotype in both $\mathrm{CD}^{+}$and $\mathrm{CD} 8^{+} \mathrm{T}$ cells in nasal polyps compared to peripheral blood mononuclear cells (PBMC) in patients with CRSwNP. Furthermore, among $\mathrm{CD}^{+} \mathrm{T}$ cells, activated regulatory $\mathrm{T}$ cells were increased in nasal polyps compared to PBMC [4]. Although $\mathrm{T}$ cells are known to be the predominant fraction of lymphocytes in polyps, other subpopulations like B cells can also be found in nasal polyps [5].

$\mathrm{B}$ cells are antigen-presenting cells and contribute to activating $\mathrm{T}$ cell help. Activated T cells interact with B cells under the influence of costimulatory molecules and cytokines, and induce signals for proliferation, survival, affinity maturation and isotype-switching. Some investigators have shown an upregulation of $\mathrm{B}$ and $\mathrm{T}$ cell interactions in nasal polyposis [6,7]. A special aspect of nasal polyps in comparison to infected nasal tissue in CRSwNP is a very high production of IgE [8]. These high local IgE levels differ from serum IgE levels in patients with CRSwNP, which underscores the importance of local IgE production [9]. Furthermore, specific IgE antibodies against Staphylococcus aureus enterotoxins were increased in nasal polyps and have a predictive value for concomitant asthma bronchiale [10]. These findings highlight the importance of local B cells in chronic infectious diseases of the nasal mucosa. They are fundamental to a variety of new-targeted approaches in CRSwNP therapy with very promising prospects [3].

Recently, immunological studies described a classification of B cells into regulatory B cells ( $\mathrm{B}_{\mathrm{reg}}$ ), mature B cells, memory B cells, plasma blasts and plasma cells. This subdivision is based on the expression of specific surface markers like CD19, CD24, CD38, CD27, CD20 and HLA-DR [11-14]. $\mathrm{B}_{\text {reg }}$ are characterized as $\mathrm{CD} 19^{+} \mathrm{CD} 20^{+} \mathrm{CD} 38^{\text {high }} \mathrm{CD} 24^{\text {high }} \mathrm{B}$ cells. In comparison, mature $\mathrm{B}$ cells intermediately express the surface markers CD38 and $\mathrm{CD} 24$, whereas memory $\mathrm{B}$ cells are $\mathrm{CD} 19^{+} \mathrm{CD} 20^{+} \mathrm{CD} 38^{-}$ $\mathrm{CD} 24^{\text {high }} \mathrm{B}$ cells. For identifying these subpopulations and analyzing the differences between peripheral and edaphic B cells, fluorescence-activated cell sorting (FACS) analysis is the method of choice $[7,15,16]$. Some investigators have shown dysregulations in the differentiation of $\mathrm{B}$ cells in autoreactive plasma cells, which can be responsible for autoimmune diseases [11]. Blair et al. [12] demonstrated an inhibition in the differentiation of $\mathrm{T}_{\mathrm{H}} 1$

\section{H I}

- Memory cells present the main B cell subpopulations in nasal polyps.

- Regulatory B cells and mature B cells significantly decrease in nasal polyps compared to peripheral blood mononuclear cell.

- Reduced regulatory B cells frequencies or high frequencies of memory B cells may cause T cell dysfunction. cells in vitro by $\mathrm{B}_{\text {reg }}$ isolated from human peripheral blood. However, this suppressive effect is lacking in patients with systemic lupus erythematosus (SLE). In addition, a correlation between the increase in $\mathrm{CD} 19^{+} \mathrm{B}$ cells and $\mathrm{CD} 27^{\text {high }}$ plasma cells and the activity of the disease in SLE is currently being discussed in the literature [11]. The aim of this study was to compare subpopulations of $\mathrm{B}$ cells in peripheral blood and nasal polyps of patients with CRSwNP using an up-to-date panel of markers for $\mathrm{B}$ cell subsets, particularly $\mathrm{B}_{\mathrm{reg}}$, in order to elucidate their influence on the etiology of this disease.

\section{MATERIALS AND METHODS}

This study was approved by the Ethics Board of the Medical Faculty, Julius-Maximilian-University Wuerzburg (vote 12/06), and all participants gave written informed consent.

\section{Preparation of human lymphocytes}

Ten milliliters of heparinized blood samples were obtained intraoperatively by venous puncture from 10 patients undergoing paranasal sinus surgery and transferred to the laboratory. Lymphocytes were separated by density-gradient centrifugation (10 minutes, $1,000 \times g$ ) at room temperature on equal amounts of Ficoll (Biochrom, Berlin, Germany), using a membrane-containing $10 \mathrm{~mL}$ cell tube (Greiner Bio-One, Frickenhausen, Germany). After washing twice in phosphate-buffered saline (PBS; Gibco BRL Life Technologies, Eggenstein, Germany), the cell number and the cell viability were determined using a Cell Counter+Analyser System (CASY TT; Innovatis, Reutlingen, Germany) according to the manufacturer's protocol. After centrifugation with $1,600 \mathrm{rpm}$ cells were frozen in $-80^{\circ} \mathrm{C}$ with 1 $\mathrm{mL}$ freezing medium, containing 10 parts fetal calf serum (Linaris, Dossenheim, Germany) and one part DMSO (Roth, Karlsruhe, Germany).

\section{Preparation of tissue samples}

All tissue samples were collected intraoperatively from $10 \mathrm{pa-}$ tients undergoing standard paranasal sinus surgery. Additionally, two samples of normal nasal tissue as control group, where collected from two patients undergoing functional septorhinoplasty or uncinectomy because of a maxillary sinus cyst. The polyps and the nasal mucosae were cut into small fragments and mashed through a cell strainer (Greiner Bio-One) from $100 \mu \mathrm{m}$ to $40 \mu \mathrm{m}$ in PBS (Gibco). After washing twice in PBS, the cell number and cell viability were determined using a CASY system according to the manufacturer's protocol. After centrifugation (5 minutes, $1,600 \mathrm{rpm}$ ) cells were frozen at $-80^{\circ} \mathrm{C}$ with 1 $\mathrm{mL}$ freezing medium.

\section{Fluorescence-activated cell sorting}

The following antibodies were used: anti-CD45 Pacific Orange, 
anti-CD19 Brilliant Violet, anti-CD20 PE, anti-CD38 antigenpresenting cells, anti-CD24 PE.Cy7, anti-CD27 Per.CP-Cy5.5 and anti-HLA-DR Alexa 700 (all by BioLegend, San Diego, CA, USA). Viability Dye 780 (eBioscience, San Diego, CA, USA) was used to detect apoptotic cells. After blocking with $25 \mu \mathrm{g} /$ $\mathrm{mL}$ normal mouse IgG (Sigma-Aldrich, St. Louis, MO, USA) for 15 minutes on ice, all cells underwent cell surface staining. All antibodies were used according to the manufacturers' instructions. FACS analyses were performed using an LSR II flow cytometer (Becton Dickinson, San Diego, CA, USA), and the data were analyzed with FlowJo software (TreeStar, Ashland, OR, USA).

\section{Statistics}

Data are presented as mean \pm standard deviation. Statistical significance was analysed by a two-tailed paired $t$-test using GraphPad Prism Software 6.0c (GraphPad Software Inc., La Jolla, CA, USA). For nonparametric distribution the Wilcoxon test was applied. The $P$-values $<0.05$ were considered statistically significant.
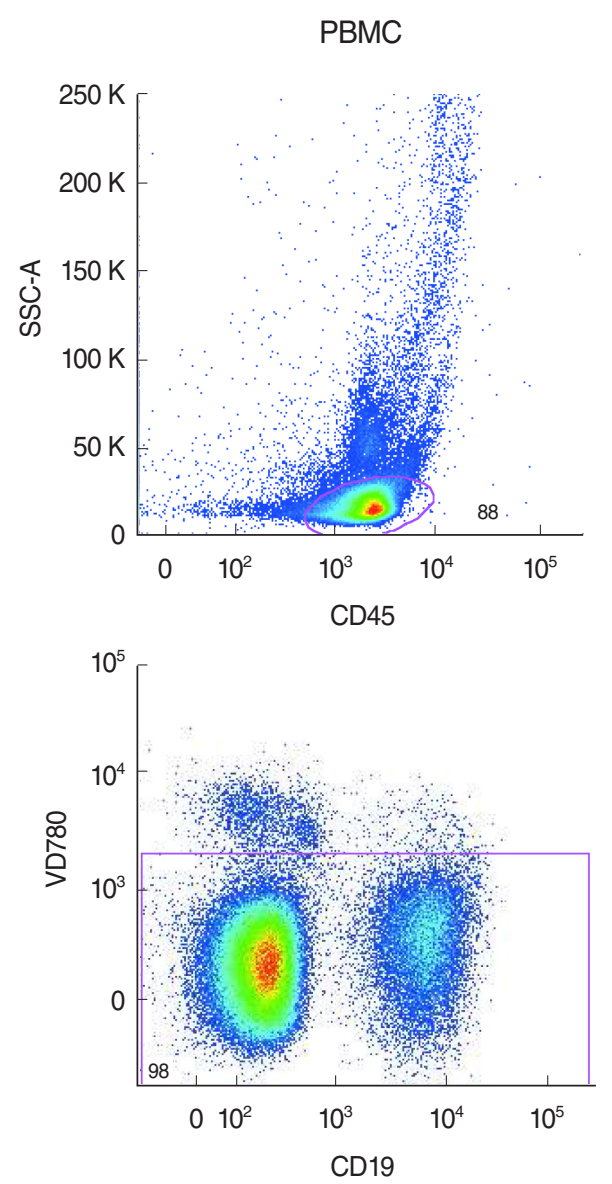

\section{RESULTS}

\section{Patient characteristics}

Ten patients were included in the study group (six males and four females). The mean age was $56 \pm 13$ years. Inclusion criteria were a chronic rhinosinusitis with nasal polyps and the failure of medical treatment. Patients with established immunodeficiency, pregnancy, coagulation disorder, classic allergic fungal sinusitis, isolated antrochoanal polyps or cystic fibrosis were excluded from the study. All patients received intranasal topical steroids prior to the surgery according to the European guidelines [17].

Table 1. Demographic and clinical characteristics of the study group

\begin{tabular}{lc}
\hline Characteristic & Value \\
\hline No. of patients & 10 \\
Age (yr), mean \pm standard deviation & $56 \pm 13$ \\
Female:male & $4: 6$ \\
Previous surgery & 3 \\
Eosinophilic polyp & 8 \\
Allergy & 4 \\
Samter's triad & 1 \\
\hline
\end{tabular}

Polyp
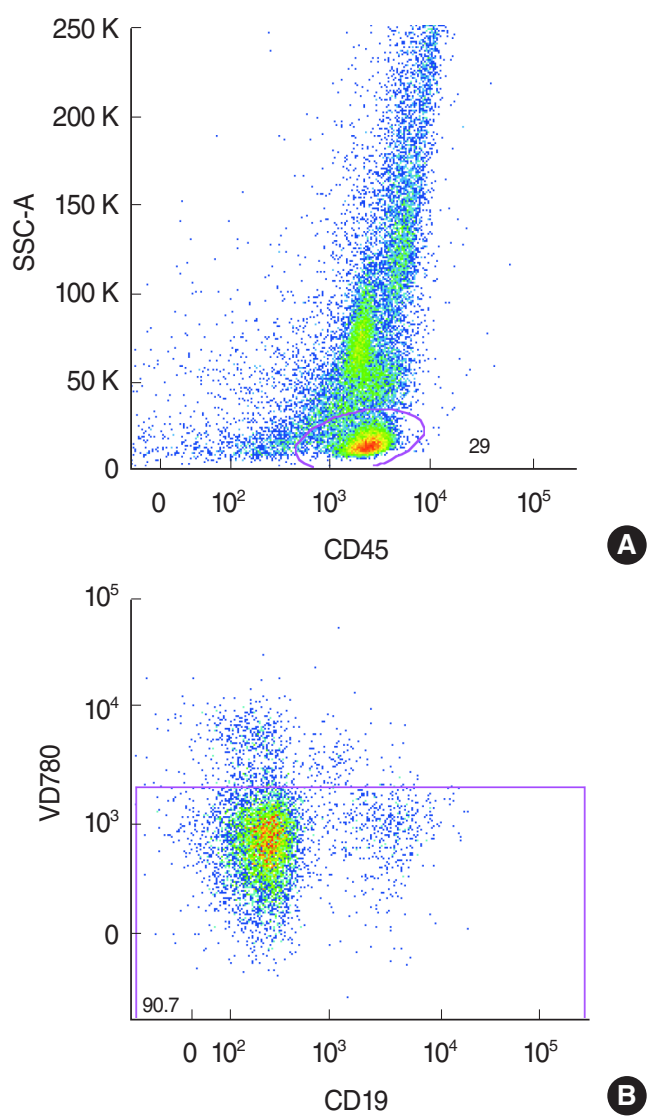

Fig. 1. (A) Detection of CD45+ lymphocytes in peripheral blood mononuclear cells (PBMC) and nasal polyps in patients with chronic rhinosinusitis with nasal polyposis (CRSwNP). (B) Separation of apoptotic cells from CD19+ lymphocytes in PBMC and nasal polyps in patients with CRSWNP. SSC-A, side scatter area. 
This treatment started weeks before surgery and if the patients did not benefit from this medical therapy a surgical intervention was planned. Eosinophilic polyposis was described in the histological evaluation in most of the patients (8 of 10). Notably, in one histological finding with no eosinophilic infiltration numerous plasma blasts and plasma cells were visible. The characteristics are summarized in Table 1. Additionally, healthy nasal mucosa was obtained from two patients undergoing functional septorhinoplasty or uncinectomy because of a maxillary sinus cyst. The median age of these patients was $47 \pm 35$ years.

\section{Significant decrease in B cells in nasal polyps compared to peripheral blood in CRSwNP}

Lymphocytes of nasal polyps and peripheral blood were analysed from 10 patients by flow cytometry by gating on $\mathrm{CD}^{4} 5^{+}$ cells (Fig. 1A) after eliminating all apoptotic cells (Fig. 1B). Then, $\mathrm{B}$ cells were identified by gating on $\mathrm{CD} 19^{+}$and $\mathrm{CD} 20^{+}$cells (Fig. 2A) and B cell subpopulations by gating on CD38 and CD24 (Fig. 2B). The $6.5 \%$ of all lymphocytes in nasal polyps were $\mathrm{CD} 19^{+} \mathrm{CD} 20^{+} \mathrm{B}$ cells (Table 2 ). The frequency of B cells in nasal
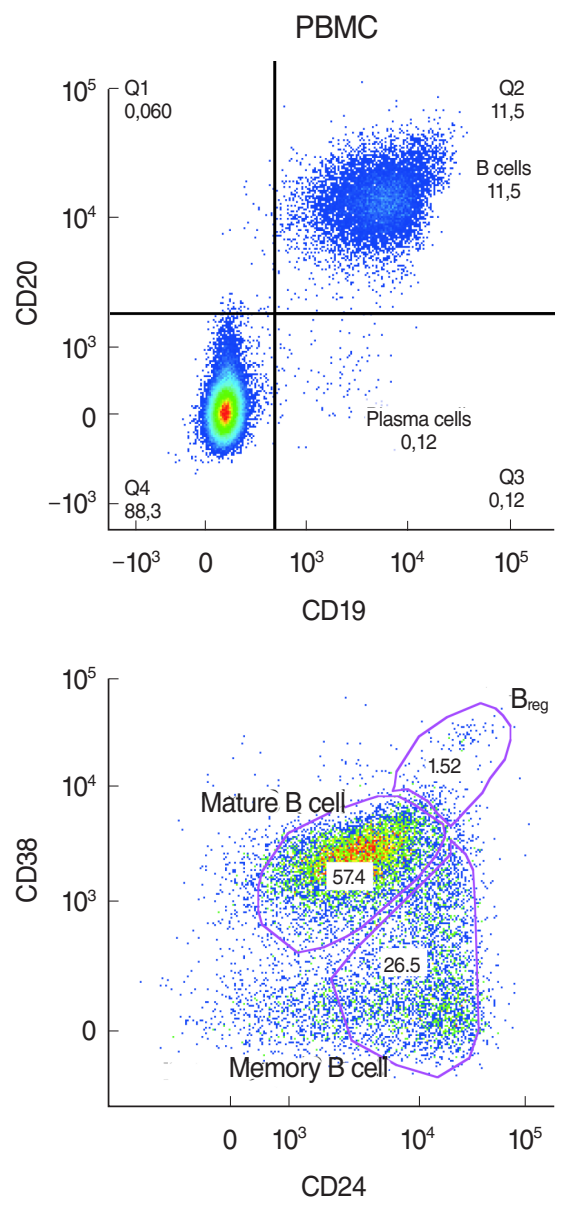

polyps was significantly lower than in PBMCs (Fig. 3A) and B cell subpopulations in nasal polyps differ from PBMCs (Fig. 3B). In healthy nasal mucosa frequencies of B cells $(4.77 \pm 0.93)$ were decreased compared to PBMCs and nasal polyps. CD19+ CD20- plasma cells were significantly higher in nasal polyps compared to PBMC and in patients with CRSwNP (Table 3) and also compared to healthy nasal tissue $(3.83 \pm 2.59)$. There

Table 2. B cell subpopulations analyzed by flow cytometry

\begin{tabular}{|c|c|c|c|}
\hline B cell & $\mathrm{PBMC}^{\mathrm{a})}$ & CRSwNPa) & $P$-value ${ }^{\text {a) }}$ \\
\hline $\mathrm{CD}_{19}{ }^{+} \mathrm{CD} 20^{+} \mathrm{B}$ cell & $11.98 \pm 6.35$ & $6.50 \pm 3.14$ & 0.028 \\
\hline CD38 ${ }^{\text {high }}$ CD24 $4^{\text {high }} B_{\text {reg }}$ & $1.90 \pm 0.98$ & $0.33 \pm 0.29$ & 0.002 \\
\hline CD38 ${ }^{\text {int }}$ CD24 $4^{\text {high }}$ mature B cell & $53.10 \pm 13.24$ & $32.36 \pm 14.49$ & $<0.001$ \\
\hline CD38- CD24 ${ }^{\text {high }}$ memory B cell & $33.65 \pm 12.86$ & $46.27 \pm 15.21$ & 0.014 \\
\hline
\end{tabular}

Values are presented as mean \pm standard deviation in percent of $10 \mathrm{pa}$ tients.

PBMC, peripheral blood mononuclear cells; CRSwNP, chronic rhinosinusitis with nasal polyposis; $B_{\text {reg, }}$ regulatory B cells.

a) Significant differences in the paired $t$-test or for nonparametric distribution the Wilcoxon test.
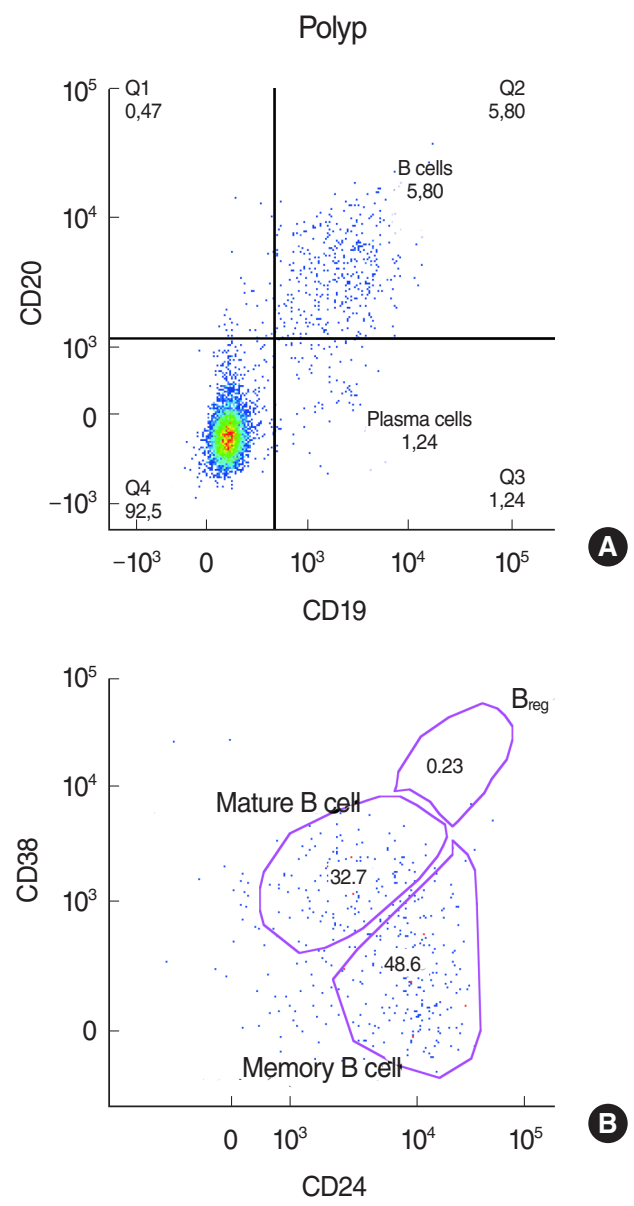

Fig. 2. (A) CD19+ CD20+ B cells and CD19- CD20 ${ }^{+}$plasma cells in peripheral blood mononuclear cells (PBMC) compared to nasal polyps in patients with chronic rhinosinusitis with nasal polyposis (CRSwNP). (B) Differentiation of regulatory $B$ cells, mature and memory $B$ cells in $\mathrm{PBMC}$ and nasal polyps by gating on CD38 and CD24. 
was no significant difference between $\mathrm{CD} 19^{+} \mathrm{CD} 20^{-} \mathrm{CD} 27^{\text {high }}$ HLA-DR ${ }^{\text {high }}$ plasma blasts and CD19+ CD20- CD27 ${ }^{\text {high }}$ HLA-

Table 3. Plasma cells and plasma blasts analyzed by flow cytometry

\begin{tabular}{|c|c|c|c|}
\hline Plasma cell & $\mathrm{PBMC}^{\mathrm{a})}$ & CRSwNPa) & $P$-value \\
\hline${\mathrm{CD} 19^{+} \text {CD20- plasma cell }}^{-}$ & $0.20 \pm 0.12$ & $10.66 \pm 15.62$ & 0.002 \\
\hline CD27 ${ }^{\text {high }} H\left\llcorner A-D R^{\text {high }}\right.$ plasma blast & $24.24 \pm 11.68$ & $16.17 \pm 12.76$ & 0.101 \\
\hline CD27 ${ }^{\text {high }}$ HLA-DR ${ }^{\text {low }}$ plasma cell & $56.79 \pm 13.03$ & $52.64 \pm 17.80$ & 0.584 \\
\hline
\end{tabular}

Values are presented as mean \pm standard deviation in percent of 10 patients.

PBMC, peripheral blood mononuclear cells; CRSWNP, chronic rhinosinusitis with nasal polyposis.

a) Significant differences in the paired t-test or for nonparametric distribution the Wilcoxon test.
$\mathrm{DR}^{\text {low }}$ plasma cells (Table 3, Fig. 4). Compared to nasal polyps and PBMCs, the lowest frequencies of $\mathrm{CD} 19^{+} \mathrm{CD} 20^{-} \mathrm{CD} 27^{\text {high }}$ HLA-DR ${ }^{\text {high }}$ plasma blasts and CD19+ CD20- CD27 $7^{\text {high }}$ HLA$\mathrm{DR}^{\text {low }}$ plasma cells were found in healthy nasal mucosa (plasma blast, 2.49 \pm 1.48 ; plasma cells, $37.60 \pm 8.20$ ).

\section{$B_{\text {reg }}$ and mature $B$ cells are significantly decreased and memory $B$ cells significantly increased in nasal polyps compared to peripheral blood in patients with CRSwNP} $\mathrm{CD} 19^{+} \mathrm{CD} 20^{+} \mathrm{CD} 8^{\text {high }} \mathrm{CD} 24^{\text {high }} \mathrm{B}_{\text {reg }}$ (Fig. 2B) were significantly lower in nasal polyps compared to PBMC in patients with CRSwNP (Table 2), but in both groups they were the minor subpopulation with only a few cells (Fig. 3B). In healthy mucosa no $\mathrm{B}_{\text {reg }}$ were detected. Mature B cells described as $\mathrm{CD} 19^{+} \mathrm{CD} 20^{+}$

\section{$\mathrm{CD} 19^{+} \mathrm{CD} 20^{+} \mathrm{B}$ cell}

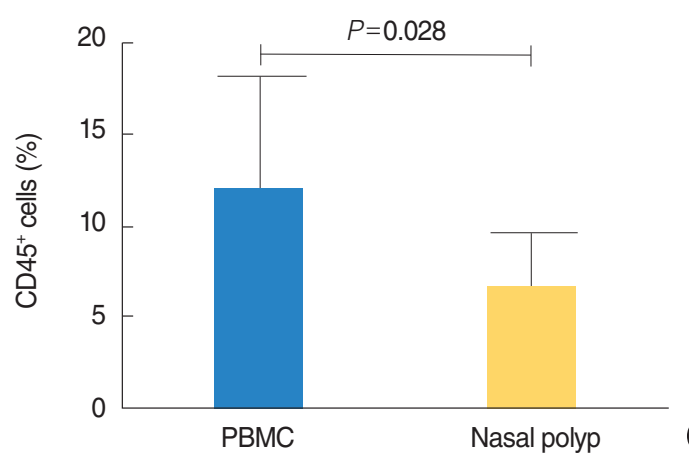

PBMC Nasal polyp

Fig. 3. (A) Amount of $B$ cells in nasal polyps compared to peripheral blood mononuclear cells (PBMC) in patients with chronic rhinosinusitis with nasal polyposis (CRSwNP). (B) Regulatory B cells ( $B_{\text {reg }}$ ), mature and memory B cells compared between lymphocytes from nasal polyps and PBMC in patients with CRSwNP.

PBMC

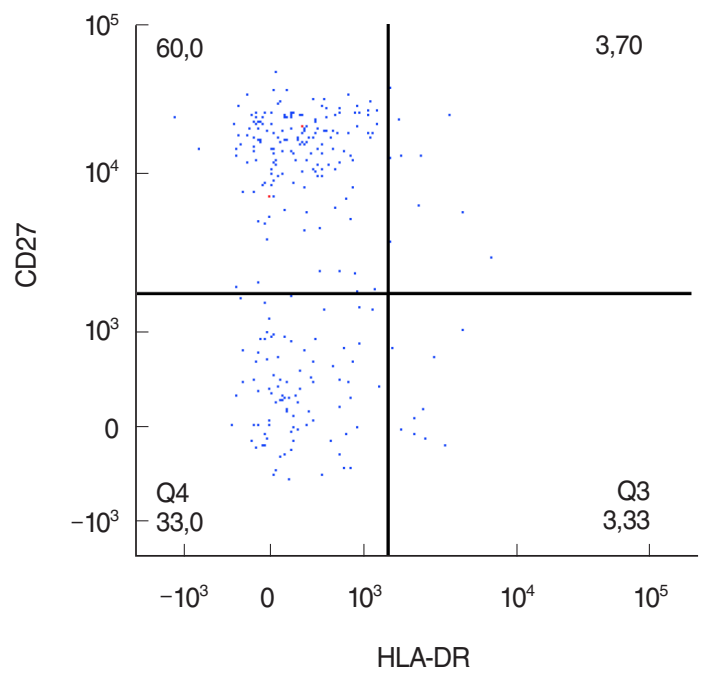

Polyp

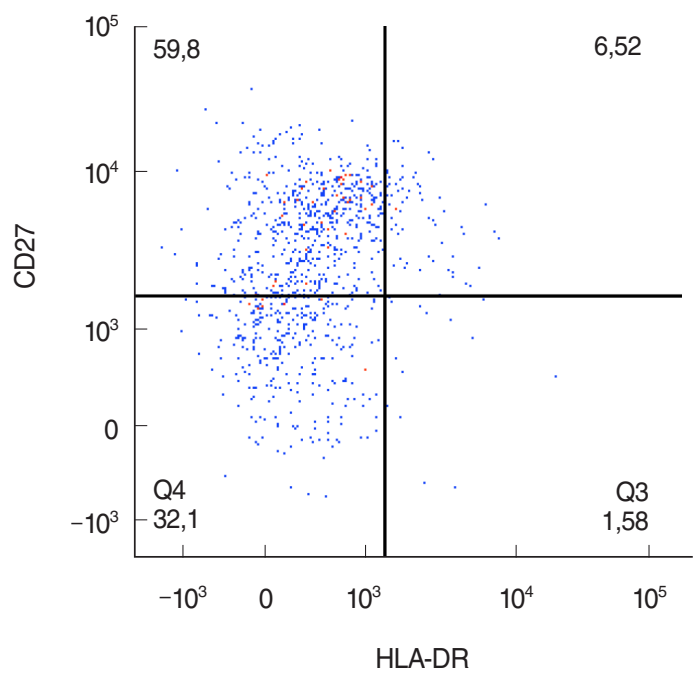

Fig. 4. Characterization of CD19+ CD20- CD27 high $H L A-D R^{\text {low }}$ plasma cells and CD19+ CD20- CD27 ${ }^{\text {high }} H L A-D R^{\text {high }}$ plasma blasts in peripheral blood mononuclear cells (PBMC) and nasal polyps in patients with chronic rhinosinusitis with nasal polyposis. 
$\mathrm{CD} 38^{\text {int }} \mathrm{CD} 24^{\text {high }} \mathrm{B}$ cells (Fig. 2B) were significantly lower in nasal polyps compared to peripheral blood (Table 2, Fig. 3B). In nasal mucosa the lowest frequencies of mature B cells (21.20土 4.24) were measured. In PBMCs, mature B cells (Fig. 2B) were the highest frequency subpopulation (Fig. 3B). CD19+ $\mathrm{CD} 20^{+}$ CD38- CD24 high memory B cells (Fig. 2B) were the main subpopulation of B cells in nasal polyps and in healthy nasal mucosa $(46.60 \pm 1.31)$. Memory B cells significantly increased in nasal polyps compared to PBMCs (Table 2, Fig. 3B).

\section{DISCUSSION}

\section{Subpopulation of B lymphocytes in CRSwNP and their impact in different diseases}

In this study, a detailed quantification of subpopulations of peripheral and edaphic B lymphocytes in CRSwNP is presented. The majority of lymphocytes in polyp tissue are T cells, particularly $\mathrm{CD} 8^{+}$cytotoxic $\mathrm{T}$ cells [18]. Furthermore, B cells may also play an important role in the pathogenesis of nasal polyps. Some investigators have already shown a possible pathogenic role of $\mathrm{B}$ cells in CRS via the inflammatory reaction of mucosal nasal tissue. Kato et al. [19] described increased levels of the B cell activating factor of the tumor necrosis factor family (BAFF) in CRSwNP, IL-6 and B-lymphocyte chemoattractant (CXCL13) [20-22], and a production of BAFF by epithelial cells. In the present study, a significantly lower frequency of $\mathrm{CD} 19^{+} \mathrm{CD} 20^{+}$ $\mathrm{B}$ cells was found in nasal polyps compared to PBMCs in patients with CRSwNP. Only $6.5 \%$ of edaphic lymphocytes in nasal polyps were B cells. Among the B cell subpopulations, $\mathrm{B}_{\text {reg }}$ and mature $\mathrm{B}$ cells were significantly lower in polypoid tissue. Memory B cells were significantly higher and represented the main subpopulation in nasal polyps compared to peripheral blood in patients with CRSwNP. In the present study, immunoglobulin-secreting plasma cells displayed a significantly higher frequency in nasal polyps compared to PBMC. Previous studies have also shown an increase in plasma cells as well, and a differentiation of B cells in nasal polyps [8] with high local production of IgE without higher serum IgE levels [9]. Memory B cells represent antigen-experienced $\mathrm{B}$ cells and are related to age: Weksler [23] showed changes in the B cell reservoir in elderly patients, which may contribute to their increased responsiveness to infections [24]. In patients with SLE, Jacobi et al. [14] found no correlation between frequency and total number of memory $B$ cells and disease duration. Furthermore, they showed a statistically significant reduction in naïve and memory B cells, but no influence of immunosuppressive therapy on plasma cells in SLE. In the European Position Paper on Rhinosinusitis and Nasal Polyps [17], a surgical treatment of CRSwNP is only indicated after failure of medical treatment and if a local therapy with corticoids does not lead to an improvement in symptoms score. Patients included in the current study received topical or systemic corticosteroids preoperatively to reduce the size of nasal polyps according to the treatment guidelines of the university hospital. Therefore, it was not possible to include a control group without any pretreatment with corticosteroids. It is very likely that this therapy may have influenced the distribution of B cell subpopulations. A study design comparing patients with and without preoperative local or systemic immunosuppressive therapy would be of great interest.

\section{Role of $\mathrm{B}_{\text {reg }}$ in autoimmune disorders}

Reduced numbers and/or function of regulatory $\mathrm{T}$ cells were demonstrated to be responsible for different types of autoimmune disorders and chronic infections [25]. Blair et al. [12] recently showed a similar population within $\mathrm{B}$ cells with regulatory functions $\left(\mathrm{B}_{\text {reg }}\right)$. They also demonstrated that $\mathrm{B}_{\text {reg }}$ could suppress $\mathrm{T}_{\mathrm{H}} 1$ differentiation by secretion of IL-10 when anti-CD 80 and CD86 $\mathrm{mAb}$ are added in vitro. In SLE, B cells isolated from peripheral blood lacked this suppressive effect. In the present study, a statistically significant decrease in $\mathrm{B}_{\mathrm{reg}}$ in nasal polyps compared to peripheral lymphocytes was shown. Future studies should focus on the functional influence of $B_{\text {reg }}$ with respect to the immunosuppressive effects on Thelper cells as in SLE [12].

\section{Effect of $B$ cells in chronic rhinosinusitis}

As previously mentioned, autoreactive $B$ cells play an important role in SLE, and preliminary attempts have been made to use B cell subset composition as a marker for disease activity [14]. Based on these findings, Tan et al. [26] attempted to examine autoreactive B cells in CRSwNP. They found production of autoantibodies in nasal polyps and concluded that these autoantibodies lead to autoimmunity. Furthermore, the investigators hypothesized that autoreactive memory B cells persist in inflammatory nasal tissue after surgery and are responsible for recurrence of nasal polyps. High frequencies of memory B cells in the present study suggest that B cell autoreactivity might be important for the development of CRSwNP. In the present study, the total number of B cells was significantly lower than in PBMCs. Although the total number of edaphic B cells was low in our observations, data from the literature indicates a key role of $\mathrm{B}$ cells in the maintenance of CRSwNP [8-10,20].

\section{Future therapeutic targets in CRSwNP}

A detailed characterization of B cell subpopulations, such as in the present study, is necessary to gain further insight into the pathophysiology of nasal polyps. The development of targeted therapies addressing CRS requires a comprehensive overview on the immunological mechanisms of this disease. Increased levels of local IgE in nasal polyps have already led to the introduction of Omalizumab as an anti-IgE treatment in clinical trials [27]. Other B cell-directed therapies, e.g., rituximab in autoimmune disease, are also promising [28], and future studies should focus on special targets like anti-dsDNA or BAFF, which are al- 
ready being investigated in clinical trials in SLE [26].

The small number of subjects limits the results of this study. A control group of healthy nasal mucosa was tried to establish. But, one problem of analysis of B cells of healthy mucosa is the very small amount of cells, so a meaningful statistical analysis is difficult. For multicolour FACS analysis more cells are necessary in the opinion of the authors. Frequencies of two samples are shown in this study to show the difference between the groups. The study is declared to be a pilot project with a limited amount of samples. Since there is no statistically significant control group with healthy mucosa, interpretation of the data is affected. For example, a significantly amount of $B_{\text {reg }}$ in nasal polyps compared to PBMC in patients with CRSwNP was observed. But, if the number of $B_{\text {reg }}$ is much lower in healthy control tissue than in polyps this would indicate that there is an accumulation of $\mathrm{B}_{\text {reg }}$ in polyps. Without a control group of healthy mucosa, it is difficult to provide further mechanistic insight. Unfortunately, analysis of B cells from healthy nasal mucosa was tried to perform but failed due to low amounts of these cells in this noninflammatory tissue, for example only a total number of $100 \mathrm{~B}$ cells were found in the first sample of healthy mucosa. In the opinion of the authors, high cell amounts are necessary for this multicolour flow cytometry analysis and for a significant analysis of this data. When assuming that most of the lymphocytes in healthy nasal mucosa were circulating intravascular cells, a control group of PBMC seemed to be equivalent, and, furthermore, a comparison of isolated T cells from tissue with PBMC is well established in the literature [4,29,30].

In this study, a detailed contemporary characterization of B cell subpopulations is presented. Memory B cells are the main subpopulation in nasal polyps. $\mathrm{B}_{\text {reg }}$ and mature $\mathrm{B}$ cells are significantly decreased in nasal polyps compared to PBMC in CRSwNP. $B_{\text {reg }}$ are necessary to suppress the $\mathrm{T}$ helper cell activation and $\mathrm{T}$ and $\mathrm{B}$ cell interaction. The question arises as to whether the reduced $B_{\text {reg }}$ frequencies cause $T$ cell dysfunction and/or the high frequencies of memory B cells. Such principle pathophysiological relationships need to be clarified in future studies and further functional studies are necessary to gain further insight into the genesis of CRSwNP [29,30].

\section{CONFLICT OF INTEREST}

No potential conflict of interest relevant to this article was reported.

\section{ACKNOWLEDGMENTS}

This work was supported in part by a grant from the Deutsche Forschungsgemeinschaft (SFB/TR 124 FungiNet, project C6), Bonn, Germany.

\section{REFERENCES}

1. Larsen PL, Tos M. Origin of nasal polyps. Laryngoscope. 1991 Mar; 101(3):305-12.

2. Andrews AE, Bryson JM, Rowe-Jones JM. Site of origin of nasal polyps: relevance to pathogenesis and management. Rhinology. 2005 Sep;43(3):180-4.

3. Bachert C, Zhang L, Gevaert P. Current and future treatment options for adult chronic rhinosinusitis: focus on nasal polyposis. J Allergy Clin Immunol. 2015 Dec;136(6):1431-40.

4. Ickrath P, Kleinsasser N, Ding X, Ginzkey C, Beyersdorf N, Hagen R, et al. Characterization of T-cell subpopulations in patients with chronic rhinosinusitis with nasal polyposis. Allergy Rhinol (Providence). 2017 Oct;8(3):139-47.

5. Dutsch-Wicherek M,Tomaszewska R, Strek P,Wicherek L, Skladzien J.The analysis of RCAS1 and DFF-45 expression in nasal polyps with respect to immune cells infiltration. BMC Immunol. 2006 Mar;7:4.

6. Zhang LP, Lin L, Zheng CQ, Shi GY. T-lymphocyte subpopulations and B7-H1/PD-1 expression in nasal polyposis. J Int Med Res. 2010 Mar-Apr;38(2):593-601.

7. Dutsch-Wicherek M, Tomaszewska R, Lazar A, Strek P, Wicherek L, Kijowski J, et al. The presence of $\mathrm{B} 7-\mathrm{H} 4+$ macrophages and CD25+CD4+ and FOXP3+ regulatory T cells in the microenvironment of nasal polyps: a preliminary report. Folia Histochem Cytobiol. 2010 Dec;48(4):611-7.

8. Gevaert P, Nouri-Aria KT, Wu H, Harper CE, Takhar P, Fear DJ, et al. Local receptor revision and class switching to IgE in chronic rhinosinusitis with nasal polyps. Allergy. 2013 Jan;68(1):55-63.

9. Van Zele T, Gevaert P, Holtappels G, van Cauwenberge P, Bachert C. Local immunoglobulin production in nasal polyposis is modulated by superantigens. Clin Exp Allergy. 2007 Dec;37(12):1840-7.

10. Bachert C, Zhang N, Holtappels G, De Lobel L, van Cauwenberge P, Liu S, et al. Presence of IL-5 protein and IgE antibodies to staphylococcal enterotoxins in nasal polyps is associated with comorbid asthma. J Allergy Clin Immunol. 2010 Nov;126(5):962-8.e1-6.

11. Hoyer BF, Manz RA, Radbruch A, Hiepe F. Long-lived plasma cells and their contribution to autoimmunity. Ann N Y Acad Sci. 2005 Jun;1050:124-33.

12. Blair PA, Norena LY, Flores-Borja F, Rawlings DJ, Isenberg DA, Ehrenstein MR, et al. CD19(+)CD24(hi)CD38(hi) B cells exhibit regulatory capacity in healthy individuals but are functionally impaired in systemic lupus erythematosus patients. Immunity. 2010 Jan;32(1): $129-40$

13. Odendahl M, Mei H, Hoyer BF, Jacobi AM, Hansen A, Muehlinghaus $\mathrm{G}$, et al. Generation of migratory antigen-specific plasma blasts and mobilization of resident plasma cells in a secondary immune response. Blood. 2005 Feb;105(4):1614-21.

14. Jacobi AM, Odendahl M, Reiter K, Bruns A, Burmester GR, Radbruch A, et al. Correlation between circulating CD27high plasma cells and disease activity in patients with systemic lupus erythematosus. Arthritis Rheum. 2003 May;48(5):1332-42.

15. Robinson DS. The role of regulatory T lymphocytes in asthma pathogenesis. Curr Allergy Asthma Rep. 2005 Mar;5(2):136-41.

16. Miyara M, Yoshioka Y, Kitoh A, Shima T, Wing K, Niwa A, et al. Functional delineation and differentiation dynamics of human CD4+ T cells expressing the FoxP3 transcription factor. Immunity. 2009 Jun;30(6):899-911.

17. Fokkens WJ, Lund VJ, Mullol J, Bachert C, Alobid I, Baroody F, et al. EPOS 2012: European position paper on rhinosinusitis and nasal polyps 2012. A summary for otorhinolaryngologists. Rhinology. 2012 Mar;50(1):1-12.

18. Derycke L, Eyerich S, Van Crombruggen K, Perez-Novo C, Holtappels G, Deruyck N, et al. Mixed T helper cell signatures in chronic 
rhinosinusitis with and without polyps. PLoS One. 2014 Jun;9(6): e97581.

19. Kato A, Truong-Tran AQ, Scott AL, Matsumoto K, Schleimer RP. Airway epithelial cells produce B cell-activating factor of TNF family by an IFN-beta-dependent mechanism. J Immunol. 2006 Nov;177(10): 7164-72.

20. Kato A, Peters A, Suh L, Carter R, Harris KE, Chandra R, et al. Evidence of a role for B cell-activating factor of the TNF family in the pathogenesis of chronic rhinosinusitis with nasal polyps. J Allergy Clin Immunol. 2008 Jun;121(6):1385-92.e1-2.

21. Patadia M, Dixon J, Conley D, Chandra R, Peters A, Suh LA, et al. Evaluation of the presence of B-cell attractant chemokines in chronic rhinosinusitis. Am J Rhinol Allergy. 2010 Jan-Feb;24(1):11-6.

22. Peters AT, Kato A, Zhang N, Conley DB, Suh L, Tancowny B, et al. Evidence for altered activity of the IL- 6 pathway in chronic rhinosinusitis with nasal polyps. J Allergy Clin Immunol. 2010 Feb;125(2): 397-403.e10.

23.Weksler ME. Changes in the B-cell repertoire with age. Vaccine. 2000 Feb;18(16):1624-8.

24. Agematsu K, Nagumo H, Yang FC, Nakazawa T, Fukushima K, Ito S, et al. B cell subpopulations separated by CD27 and crucial collaboration of $\mathrm{CD} 27+\mathrm{B}$ cells and helper $\mathrm{T}$ cells in immunoglobulin pro- duction. Eur J Immunol. 1997 Aug:27(8):2073-9.

25. Belkaid Y,Tarbell K. Regulatory T cells in the control of host-microorganism interactions (*). Annu Rev Immunol. 2009 Apr;27:551-89.

26. Tan BK, Li QZ, Suh L, Kato A, Conley DB, Chandra RK, et al. Evidence for intranasal antinuclear autoantibodies in patients with chronic rhinosinusitis with nasal polyps. J Allergy Clin Immunol. 2011 Dec;128(6):1198-206.e1.

27. Gevaert P, Calus L, Van Zele T, Blomme K, De Ruyck N, Bauters W, et al. Omalizumab is effective in allergic and nonallergic patients with nasal polyps and asthma. J Allergy Clin Immunol. 2013 Jan; 131(1):110-6.e1.

28. Dorner T, Radbruch A, Burmester GR. B-cell-directed therapies for autoimmune disease. Nat Rev Rheumatol. 2009 Aug;5(8):433-41.

29. Murray T, Fuertes Marraco SA, Baumgaertner P, Bordry N, Cagnon L, Donda A, et al. Very late antigen-1 marks functional tumor-resident CD8T cells and correlates with survival of melanoma patients. Front Immunol. 2016 Dec;7:573.

30. Rau M, Schilling AK, Meertens J, Hering I, Weiss J, Jurowich C, et al. Progression from nonalcoholic fatty liver to nonalcoholic steatohepatitis is marked by a higher frequency of TH17 cells in the liver and an increased TH17/resting regulatory T cell ratio in peripheral blood and in the liver. J Immunol. 2016 Jan;196(1):97-105. 